\title{
An Assessment of the Impact and Benefits of Total Productive Maintenance (Tpm) On Manufacturing Profitability: A Case Study of a Food Processing Industry in Nigeria
}

\author{
${ }^{1}$ Kalwang, M. M., ${ }^{2}$ Kulla D. M., ${ }^{3}$ Agontu J.A.,${ }^{4}$ Mafai, G. S \\ ${ }^{1}$ Formally Operations Engineer, Grand Cereals and Oil Mills (GCOML) Ltd, Jos-Nigeria \\ ${ }^{2}$ Department of Mechanical Engineering, Ahmadu Bello University, Zaria-Nigeria \\ ${ }^{3}$ Department of Mechanical Engineering, Plateau State Polytechnic, Barkinladi-Nigeria \\ ${ }^{4}$ Formally Chief Engineer, Grand Cereals and Oil Mills (GCOML) Ltd, Jos-Nigeria
}

\begin{abstract}
This study was carried out to assess the impact and benefits of Total Productive Maintenance on manufacturing profitability awareness for Grand Cereals Ltd., Jos-Nigeria). The research objective is to assess the impact and benefits of TPM on manufacturing profitability of the company. Data relevant to the study were collected using designed questionnaire, structured interviews, direct observations and company records. The Statistical Package for Social Sciences (SPSS) and Microsoft Excel were used in analysing the data obtained. The results show that the frequency of machine and equipment breakdowns is $58 \%$ often and $42 \%$ rarely. The research also reviewed that $84 \%$ of machine operators were not involved in maintenance activities with only $16 \%$ involvement. As regards to the effectiveness of the maintenance technique(s) used, $76 \%$ was rated good while 24\% was rated fair. Cereal Mill Overall Plant Effectiveness (OPE) was obtained at $38 \%$ which was below the world class standard by almost $50 \%$. Equipment downtime was a major cause of plant underutilization with $91 \%$ caused by shortage of critical spare parts and $9 \%$ shortage of raw materials. On TPM awareness, $80 \%$ of the employees have been aware of the TPM concept while $98 \%$ indicated the concept of TPM would help improve the current maintenance system and $2 \%$ were not sure. $20 \%$ of the employees were not aware of TPM while $80 \%$ of employees indicated that the company does not implement TPM, with 20\% not sure that the TPM concept can help improve the current maintenance system. Based on these results, knowledge and information sharing, operator involvement, engagement of all employees from top management to lower level and training should be considered. The effective implementation of TPM model could increase the competition of the company in the dynamic business environment. Thus, adoption and effective implementation of TPM is recommended for the company towards achieving improvement in its manufacturing profitability.
\end{abstract}

Keywords: Impact, implementation, Potentials, Profitability, Total Productive Maintenance (TPM).

\section{Introduction}

The degree to which machine and equipment breakdown can affect profitability, quality of goods and services, safety, environment and increase pressure to achieve high plant availability that can balance the market demand at reduced costs should be the area of priority of companies if they must remain dominant key players in a highly competitive economy as it is globally today. It must resort to various strategies to remain in business. The five key performance objectives used by manufacturing industries to remain competitive and maintain good market share are, pricing, speed, dependability, flexibility and quality (Madanhire and Mbohwa,2015). Thus, it is important to measure the performance and efficiency of business operations with a view to coming up with ways of improving it. To achieve improvement in profitability, quality and safety in a manufacturing operation, implementation of Total Productive Maintenance (TPM) is imperative. TPM aims at putting together best maintenance practices for capital intensive continuous batch production processes to improve machine and equipment efficiency and material yield that can lead to a firm's improved profitability, productivity and competitiveness (Renganathan, 2014). TPM concept is based on 
the fact that productivity can be improved if operators and technicians carry out daily inspections, lubrication, parts replacement, troubleshooting, accurate checks/settings, repairs, etc. on plant machines and equipment with the aim of 'keeping one's own equipment in good condition by oneself' machine reliability is greatly improved if such practices are put in place.

Most companies in Nigeria however, practice less of preventive and planned maintenance and this has caused a lot of breakdowns resulting in high cost of maintenance, low plant availability, low capacity utilization and impacting negatively on productivity. This study is aimed at creating awareness on the implementation of TPM and for manufacturing industries in Nigeria to appreciate the impact and benefits of this maintenance strategy with a view to exploring these benefits to achieve operational growth and boost the economy. Grand Cereals and Oil Mills Limited, a subsidiary of United African Company (UAC) Nigeria plc. Jos, Plateau State shall be used as a case study.

\section{Materials and Method}

The study employed the survey research design that involved collection and analysis of data by administering questionnaires to areas of interest. Also, in addition to the questionnaires, interviews were granted where necessary and relevant data were sourced to assess the manufacturing productivity and the maintenance technique(s) currently employed. Library and desk research was also engaged as some needed facts were researched from other materials and existing literature.

A total of 50 employees were sampled out of 200 employees using stratified sampling method. A sampling intensity of $25 \%$ was used as it minimizes the sampling error. According to Struwig and Stead (2010), 25\% sampling intensity is recommended and acceptable for selecting samples from each population. A total of 50 Questionnaires were administered to some selected Management, Supervisors and Staff of the company comprising of engineers, technicians, production managers, production supervisors and machine operators. In order to minimize bias, they were picked in strata from the sample population of 200 engineering and production employees.

\subsection{Sampling Technique and Method of Data Collection}

The sampling tech nique used was the questionnaire. A set of the designed questionnaire was administered to each stratified sample of the larger population (engineering and production departments) which contain 41 questions on the employee personal and organization profile, awareness of Total Productive Maintenance concept, Impact of maintenance activities, Constraints of maintenance, TPM benefits, and general company information and the maintenance technique(s) currently being practiced by the company. Empirical observations were also made in the factory floor to assess the manufacturing performance. Access was requested to relevant materials such as monthly Production volume achieved, maintenance cost and overall annual business revenue generated and profit earned for a period of seven years. The questionnaire was used as it was seen as a justifiable way to get original primary data that actually represent the opinion of the human resource and afforded the respondents to express their true opinions without reservation or external influence.

\subsection{Data Presentation and Analysis}

The Statistical Package for Social Sciences (SPSS) was used in analyzing the data. Strata 13 test (regression table) was also used to draw conclusions on the impact of plant availability, capacity utilization and maintenance cost on turnover (Production output).

\section{Results and Discussions}

Data obtained from questionnaire respondents, review of documents, personal observations were analysed and the findings used to solve the problem of the research work and thus arriving at appropriate conclusions and recommendations

\subsection{Analysis of Questionnaires Distributed}

Table 3.1: Analysis of questionnaires distributed and returned

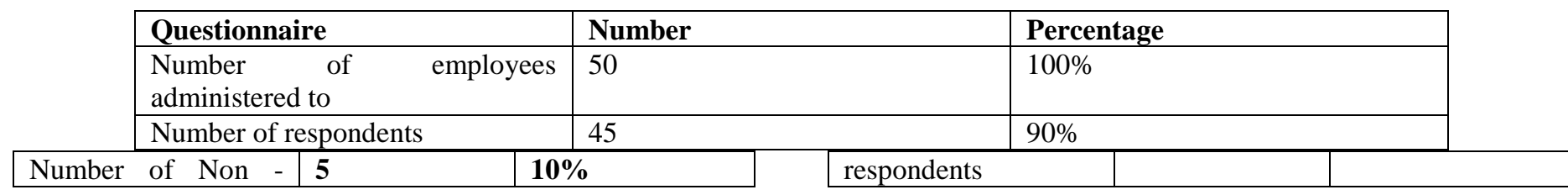


Table 3.1 shows that $90 \%$ of the questionnaire distributed was filled and returned by respondents while $10 \%$ was not returned by respondents. Thus, the entire analysis was focused on $90 \%$ returned which helped in arriving at valid and reliable results.

\subsection{Presentation of Results}

Five sections of the questionnaires were administered to each selected employee of technical and production departments. The first section contains ten socio-demographic questions which assessed employee personal and organization profile. The second section contains five questions asked to assess the awareness of Total Productive Maintenance concept. The third section contains fourteen questions structured to assess the impact of maintenance activities. The fourth section also contains five questions asked to assess the constraints of maintenance while the last section five which contains seven questions asked to assess the benefits of TPM methodology. including summary on the number of questionnaires administered, responded and retrieved across different demographic variables as shown in Table 3.2 below indicate that $95.6 \%$ of the respondents were male and $4.4 \%$ of the respondents were female. This disparity indicated male dominance not only in technical activities but also in the field of production. Twenty six (26) respondents representing $57.8 \%$ of the total respondents were staff of technical department and Nineteen (19) respondents representing 42.2\% were production staff. The table alsshows that $42.2 \%$ of the sampled population had ' $\mathrm{O}$ ' Level educational qualification, $26.7 \%$ had HND certificates, $15.6 \%$ had OND certificates, and $11.1 \%$ had B.SC degree while $4.4 \%$ hold Masters Degree. The analysed result shows that majority of the staff of both technical and production departments had the minimum qualification ('O' level certificates).

\subsection{Socio-Demographic Data}

The socio-demographic analysis of the respondents is reflected on tables and charts

Table 3.2: Demographic Distribution of Respondents

\begin{tabular}{|l|l|l|l|}
\hline Characteristics & & Frequency & Percentage \\
\hline Gender & Male & 43 & 95.6 \\
\hline & Female & 2 & 4.4 \\
\hline & & & \\
\hline Department & Technical & 26 & 57.8 \\
\hline & Production & 19 & 42.2 \\
\hline & & & \\
\hline Qualification & O' Level & 19 & 42.2 \\
\hline & OND & 7 & 15.6 \\
\hline & HND & 12 & 26.7 \\
\hline & B.Sc. & 5 & 11.1 \\
\hline & M.Sc. & 2 & 4.4 \\
\hline & & & \\
\hline Industrial experience & Below 5 Years & 24 & 53.3 \\
\hline & 6-10 Years & 8 & 17.8 \\
\hline & $11-15$ Years & 7 & 15.6 \\
\hline & $16-20$ Years & 3 & 6.7 \\
\hline & $21-25$ Years & 2 & 4.4 \\
\hline & 26-30 Years & 1 & 2.2 \\
\hline & & 25 & \\
\hline & Below 5 Years & 7 & 55.6 \\
\hline & 6-10 Years & 7 & 15.6 \\
\hline & $11-15$ Years & 3 & 6.7 \\
\hline & $16-20$ Years & & \\
\hline & & 25.6 & \\
\hline
\end{tabular}




\begin{tabular}{|l|l|l|l|}
\hline & $21-25$ Years & 2 & 4.4 \\
\hline & $26-30$ Years & 1 & 2.2 \\
\hline & & & \\
\hline Employee Job Level & Management & 10 & 22.2 \\
\hline & Supervisor & 13 & 28.9 \\
\hline & Staff & 22 & 48.9 \\
\hline
\end{tabular}

Source: Researcher's Field Survey, 2018

\subsection{Employees Industrial Experience}

The distribution of respondents by years of industrial experience showed that 24 and 8 out of the total respondents representing $53.3 \%$ and $17.8 \%$ have worked for less than five years and Six to ten years respectively, 7 and 3 respondents representing $15.6 \%$ and $6.7 \%$ had also worked for eleven to fifteen years and sixteen to twenty years respectively. This implied that most of the employees in the technical and production departments have not acquired adequate industrial training to effective manage the plants.

\subsection{Employees years of service}

The distribution of respondents by year of service revealed that 25 and 7 out of the total respondents representing $55.6 \%$ and $15.6 \%$ have worked below five years and six to fifteen years, 3 respondents representing $6.7 \%$ had worked within sixteen to twenty while $4.4 \%$ and $2.2 \%$ have worked between twenty one to twenty- five years and twenty- six to thirty years respectively. This clearly shows that most of the respondents have worked for five to fifteen years.

\subsection{Awareness of TPM Methodology}

This section contains the presentation and analysis of the questions targeted at determining the awareness of Total Productive Maintenance Concepts and is outlined in the table 3.3.

On the respondent's level of awareness about total productive maintenance (TPM) Methodology, out of the 45 respondents, 36 employees, accounting for $80 \%$ of the respondents indicated that they have heard about TPM methodology while the remaining 20\% did not know about TPM.

Table 3.3: Results for level of Awareness of TPM Concepts

\begin{tabular}{|l|l|l|}
\hline Statements & Frequency & Percentage \\
\hline Do you know about total productive maintenance (TPM) Methodology? & & \\
\hline Yes & 36 & 80.0 \\
\hline No & 9 & 20.0 \\
\hline Do you believe in TPM Methodology? & & \\
\hline Yes & 44 & 97.8 \\
\hline No & 1 & 2.2 \\
\hline Has your company implemented TPM? & & \\
\hline Yes & 9 & 20.0 \\
\hline No & 36 & 80.0 \\
\hline Does your company has separates TPM office? & & \\
\hline Yes & 3 & 6.7 \\
\hline No & 42 & 93.3 \\
\hline According to you what are the major sources of complaints? & & \\
\hline Operators complaint & 11 & 24.4 \\
\hline Condition of machine & 26 & 57.8 \\
\hline
\end{tabular}




\section{Source: Researcher's Field Survey, 2018}

On the prospects of TPM Methodology, $97.8 \%$ of the respondents believe in its prospects while $2.2 \%$ do not and 36 out of 45 respondents, accounting for $80 \%$ of the respondents reported that Grand Cereals Ltd has not implemented TPM while 9 respondents, accounting for $20 \%$ indicated that the company has implemented TPM. On the major sources of complaints in the organisation, $57.8 \%$ of the respondents attributed the major sources of complaints to condition of Machines and equipment, $24.4 \%$ of the respondents reverted that operator complaints are the major sources of complaints while $17.8 \%$ of respondents showed that working condition is the major source of complaint. Madanhire and Mbohwa (2015) stated in their survey carried out on implementing successful TPM in manufacturing plant that overall performance of the company was increased after the implementation.

\subsection{The impact of maintenance activities}

This section contains the presentation and analysis of the questions targeted at determining the impact of maintenance activities.

\section{Table 3.4: Impact of Maintenance activities}

\begin{tabular}{|l|l|l|l|l|l|l|l|}
\hline $\mathbf{1}$ & Statement & Poor & Average & Neutral & Good & Very good & Mean \\
\hline $\begin{array}{l}\text { What is the impact } \\
\text { maintenance }\end{array}$ & - & $1(2.2 \%)$ & $4(8.9 \%)$ & $29(64.4 \%)$ & $11(24.4)$ & 4.11 \\
\hline $\mathbf{2}$ & $\begin{array}{l}\text { What is the impact } \\
\text { of local fabrication } \\
\text { of spares on } \\
\text { maintenance }\end{array}$ & $3(6.7 \%)$ & $3(6.7 \%)$ & $29(64.4 \%)$ & $10(22.2 \%)$ & 4.02 \\
\hline $\mathbf{3}$ & $\begin{array}{l}\text { What is the impact } \\
\text { of overtime on } \\
\text { output? }\end{array}$ & $2(4.4 \%)$ & $6(13.3 \%)$ & $9(20.0 \%)$ & $17(37.8 \%)$ & $11(24.4 \%)$ & 3.64 \\
\hline $\mathbf{4}$ & $\begin{array}{l}\text { What is the impact } \\
\text { of spare parts cost on } \\
\text { output? }\end{array}$ & $14(31.1 \%)$ & $10(22.2 \%)$ & $21(46.7 \%)$ & - & 2.16 \\
\hline $\mathbf{5}$ & $\begin{array}{l}\text { What is the impact } \\
\text { of plant availability } \\
\text { and utilization on } \\
\text { production output? }\end{array}$ & - & $3(6.7 \%)$ & $28(62.2 \%)$ & $14(31.1 \%)$ \\
\hline
\end{tabular}

\section{Source: Researcher's Field Survey, 2018.}

In order to respond to the research questions raised for the study, a mean score of 2.5 was used for the decision for and against. A mean score of 2.5 and above meant agreement while mean score lower than the 2.5 midpoint implied disagreement. Hence, the impact of traditional maintenance, local fabrication of spare on maintenance, plant availability and production output was good, while impact of spare parts cost on output was poor or average, same with over time on production output.

\section{Table 3. 4.1: Impact of Maintenance activities}

\begin{tabular}{|l|l|l|}
\hline Statements & Frequency & Percentage \\
\hline $\begin{array}{l}\text { Is there prior maintenance activities carried out before } \\
\text { production commences? }\end{array}$ & & \\
\hline Yes & 45 & 100.0 \\
\hline
\end{tabular}




\begin{tabular}{|c|c|c|}
\hline No & 0 & 0.0 \\
\hline \multicolumn{3}{|c|}{ Preventive Maintenance } \\
\hline Yes & 34 & 75.6 \\
\hline No & 11 & 24.4 \\
\hline \multicolumn{3}{|c|}{ Breakdown or Corrective Maintenance } \\
\hline Yes & 17 & 37.8 \\
\hline No & 28 & 62.2 \\
\hline \multicolumn{3}{|c|}{ Planned Maintenance } \\
\hline Yes & 16 & 35.6 \\
\hline No & 29 & 64.4 \\
\hline \multicolumn{3}{|c|}{ Do you have schedule maintenance in place? } \\
\hline Yes & 43 & 95.6 \\
\hline No & 2 & 4.4 \\
\hline \multicolumn{3}{|c|}{ Daily } \\
\hline Yes & 7 & 15.6 \\
\hline No & 38 & 84.4 \\
\hline \multicolumn{3}{|c|}{ Weekly } \\
\hline Yes & 12 & 26.7 \\
\hline No & 33 & 73.3 \\
\hline \multicolumn{3}{|c|}{ Monthly } \\
\hline Yes & 22 & 48.9 \\
\hline No & 23 & 51.1 \\
\hline \multicolumn{3}{|c|}{ Quarterly } \\
\hline Yes & 6 & 13.3 \\
\hline No & 39 & 86.7 \\
\hline \multicolumn{3}{|c|}{ Half Yearly } \\
\hline Yes & 1 & 2.2 \\
\hline No & 44 & 97.8 \\
\hline \multicolumn{3}{|c|}{ Annually } \\
\hline Yes & 2 & 4.4 \\
\hline No & 43 & 95.6 \\
\hline
\end{tabular}

Assessment of the type of maintenance practice used by Grand Cereals Ltd. And its impact on manufacturing profitability was carried out. The maintenance of the Plants is done by technical department using the traditional maintenance strategy (preventive, breakdown and planned) which means the absence of TPM. More of breakdown maintenance was carried out with less of preventive and planned maintenance.

The respondents indicated that only daily maintenance plan has been implemented while weekly, monthly, half yearly and annual maintenance was not carried out.

\section{Table 3.4.2: Impact of Maintenance activities}




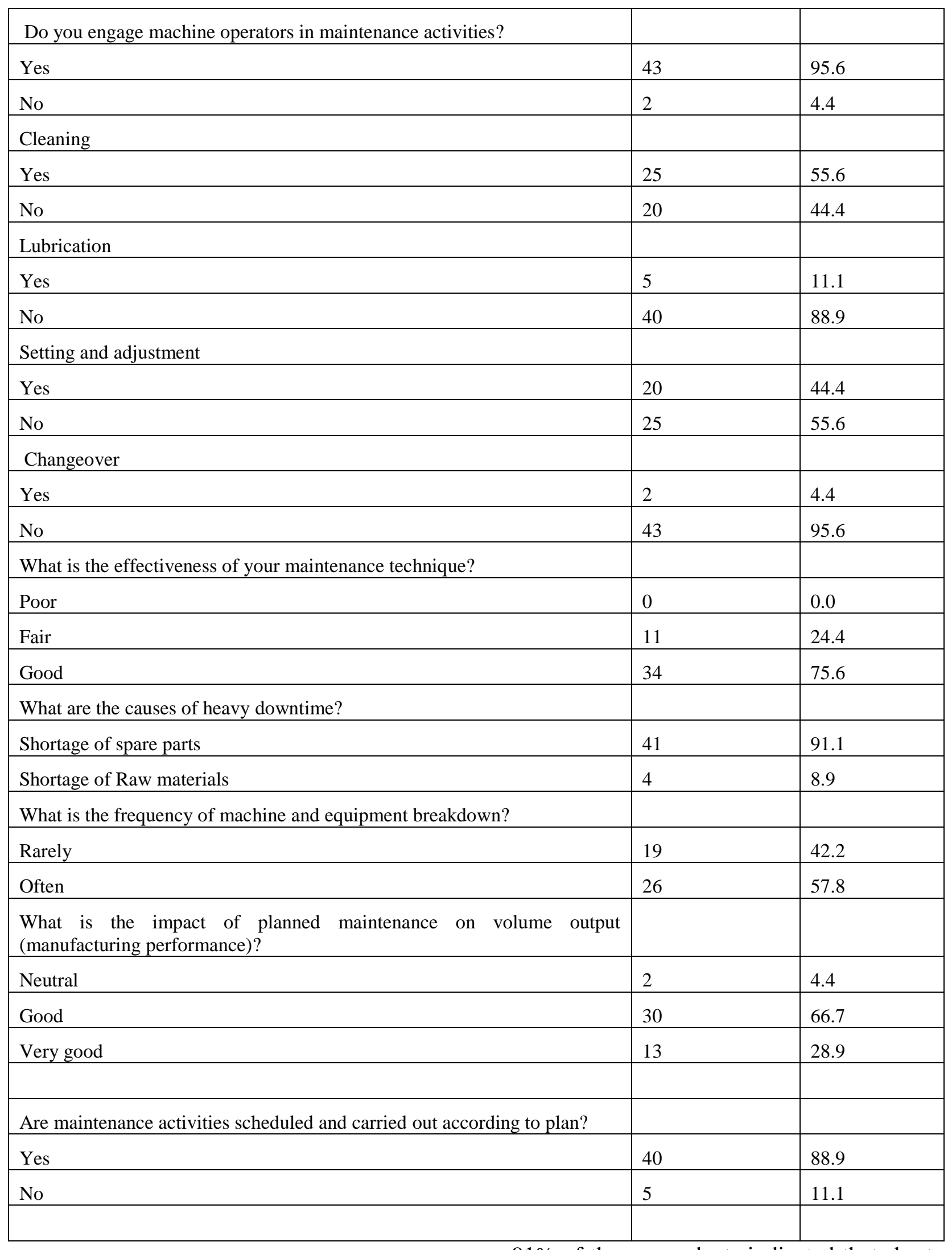

From the survey carried out, the main source of complaint was the condition of machines and equipment in the plants. The operators of these machines are responsible for the up-keep of their equipment to avoid deterioration. It was observed however, that the machine operators' role does not include carrying out repairs but only cleaning.
$91 \%$ of the respondents indicated that shortage of spares caused heavy downtime while $57.8 \%$ reported that machines and equipment break down more often.

Mwanza and Mbohwa (2015) designed a TPM model for effective implementation in a chemical manufacturing company. In that survey, it was 
found out that the reasons for lack of operator involvement in maintenance activities were: lack of appropriate knowledge and skills for maintenance, lack of specialization, unwillingness to accept more responsibilities and the prevailing culture in the company. However, the few operators that were involved did so because they understood the operation of the equipment thus could detect abnormalities easily and earlier than

the maintenance personnel counterparts. Seng et al. (2017) worked on "implementing total productive maintenance (TPM) in a Malaysian manufacturing organization: an operational strategy study" in which it was concluded that both human and process oriented strategies would lead to higher TPM implementation and organization. However the impact of humanoriented strategy was found to have a greater impact than process oriented strategy in enhancing higher extent of TPM implementation, thus there ought to be a balance between both to bring about an optimization of implementation. Chan et al. (2005) looked into "the implementation of TPM using the semiconductor industry in Hong Kong as a case study where they found out that after implementation of TPM, both tangible and intangible benefits were obtained for both equipment by way of reduced number of stoppages and employees by way of the development of "can-do" attitude and sense of ownership. The productivity of the model machine used increased by $83 \%$.

\section{Table 3.4.3: Impact of Maintenance activities}

\begin{tabular}{|l|l|l|l|}
\hline Statements & Frequency & Percentage & Mean \\
\hline $\begin{array}{l}\text { What is the impact of traditional } \\
\text { maintenance on availability? }\end{array}$ & & & \\
\hline Poor & & & \\
\hline Average & 1 & 2.2 & \\
\hline Neutral & 4 & 8.9 & \\
\hline Good & 29 & 64.4 & \\
\hline Very Good & 11 & 24.4 & \\
\hline $\begin{array}{l}\text { What is the impact of local fabrication on } \\
\text { maintenance? }\end{array}$ & & & \\
\hline Poor & - & - & \\
\hline Average & 3 & 6.7 & \\
\hline Neutral & 3 & 6.7 & \\
\hline Good & 29 & 64.4 & \\
\hline Very Good & 10 & 22.2 & \\
\hline $\begin{array}{l}\text { What is the impact of overtime on } \\
\text { output? }\end{array}$ & & & \\
\hline Poor & 2 & 37.8 & \\
\hline Average & 6 & 24.4 & \\
\hline Neutral & 9 & 13.3 & \\
\hline Good & 17 & 20.0 & \\
\hline Very Good & 11 & & \\
\hline $\begin{array}{l}\text { What is the impact of spare parts cost on } \\
\text { output? }\end{array}$ & 14 & & \\
\hline Poor & & & \\
\hline
\end{tabular}




\begin{tabular}{|l|l|l|l|}
\hline Average & 10 & 22.2 & \\
\hline Neutral & 21 & 46.7 & \\
\hline Good & - & - & \\
\hline Very Good & - & & \\
\hline $\begin{array}{l}\text { What is the impact of plant availability } \\
\text { and utilization on production output? }\end{array}$ & & & \\
\hline Poor & - & - & \\
\hline Average & - & - & \\
\hline Neutral & 3 & 6.7 & \\
\hline Good & 28 & 62.2 & \\
\hline Very Good & 14 & 31.1 & \\
\hline & & & \\
\hline
\end{tabular}

On assessment of the impact of maintenance activities, $64.4 \%$ of the respondents indicated that the current maintenance practice and local fabrication of spares by the company is good.37.8\% agreed that the impact of overtime is also good.46.7\% indicated that the impact of spare parts costs on production output is neutral while

$31 \%$ agreed that it is poor. Finally, $62.2 \%$ reported that the availability and utilization achieved as a result of the current traditional maintenance practice is good. Thus, maintenance is considered as profit centre and not a cost centre.

\subsection{Constraints of maintenance}

This section contains the presentation and analysis of the questions targeted at determining the constraints of maintenance activities.

\section{Table 3.5: Constraints of maintenance}

\begin{tabular}{|l|l|l|}
\hline Statements & Frequency & Percentage \\
\hline Are there bottle-necks at any stage of maintenance activities & & \\
\hline Yes & 40 & 88.9 \\
\hline No & 5 & 11.1 \\
\hline Lack of funds & & \\
\hline Yes & 18 & 40.0 \\
\hline No & 27 & 60.0 \\
\hline Lack of tools and spare parts available in the company & & \\
\hline Yes & 27 & 60.0 \\
\hline No & 18 & 40.0 \\
\hline Lack of manpower & & \\
\hline Yes & 29 & 64.4 \\
\hline No & 16 & 35.6 \\
\hline Lack of skilled and trained employees in the company & & \\
\hline Yes & 17 & 37.8 \\
\hline No & 28 & 62.2 \\
\hline & & \\
\hline
\end{tabular}

Source: Researcher's Field Survey, 2018 
40 out of 45 respondents, accounting for $88.9 \%$ agreed that there are bottle-necks encountered at each stage of maintenance activities while the remaining 5(11.1\%) objected. For employees that agreed reported that the maintenance constraints are due to lack of funds, special tools, critical spare parts and lack of skilled and trained manpower in the company.

\subsection{The benefits of Total Productive Maintenance (TPM)}

This section contains the presentation and analysis of the questions targeted at determining the benefits of Total Productive Maintenance.

\section{Table 3.6: TPM - Benefits}

\begin{tabular}{|c|c|c|}
\hline Statements & Frequency & Percentage \\
\hline \multicolumn{3}{|c|}{ Did you find TPM useful in your company? } \\
\hline Yes & 45 & 100.0 \\
\hline No & - & - \\
\hline \multicolumn{3}{|c|}{ Higher productivity } \\
\hline Yes & 44 & 97.8 \\
\hline No & 1 & 2.2 \\
\hline \multicolumn{3}{|c|}{ Reduction in production cost after TPM implementation } \\
\hline Yes & 42 & 93.3 \\
\hline No & 3 & 6.7 \\
\hline \multicolumn{3}{|c|}{ Reduction of breakdown after TPM Implementation } \\
\hline Yes & 43 & 95.6 \\
\hline No & 2 & 4.4 \\
\hline \multicolumn{3}{|c|}{ Improved product quality } \\
\hline Yes & 44 & 97.8 \\
\hline No & 1 & 2.2 \\
\hline \multicolumn{3}{|c|}{ Increased customer satisfaction } \\
\hline Yes & 44 & 97.8 \\
\hline No & 1 & 2.2 \\
\hline \multicolumn{3}{|c|}{ Higher employee motivation } \\
\hline Yes & 33 & 73.3 \\
\hline No & 12 & 26.7 \\
\hline
\end{tabular}

\section{Source: Researcher's Field Survey, 2018}

$100 \%$ of the respondents indicated that TPM is useful to the company if implemented. The anticipated benefits that are derivable are: higher productivity, reduction in production cost, improved product quality, increased customer satisfaction and higher employee motivation.

Table 3.7: The impact of Plant availability, Utilization and Maintenance cost on turnover (production output)

\begin{tabular}{|l|l|l|l|l|l|l|}
\hline Source & SS & df & MS & Number of obs & & 84 \\
\hline
\end{tabular}




\begin{tabular}{|l|l|l|l|l|l|l|}
\hline & & & & F( 3, 80) & & 239.60 \\
\hline Model & 8.20365852 & 3 & 2.73455284 & Prob. > F & 0.0000 \\
\hline Residual & 0.913033464 & 80 & .011412918 & R-squared & & 0.8999 \\
\hline & & & & Adj. R-squared & & 0.8961 \\
\hline Total & 9.11669198 & 83 & .109839662 & Root MSE & & .10683 \\
\hline
\end{tabular}

Source: State 13 output from Grand cereals company (2010-2016) report

Table 3.7 above shows the analysis of variance table and the parameter estimates. In the former, the ratio of the model mean square to the residual mean square gives an $F$-test for the hypothesis that all the regression coefficients in the fitted model are zero (accept the constant $\beta_{0}$ ). The resulting $F$-statistic with $(3,80)$ degrees of freedom takes the value 239.6 with associated $p$ value $<0.001$. Consequently, the hypothesis is rejected. The square of the multiple correlation coefficient $\left(R^{2}\right)$ is 0.896 showing that $89.6 \%$ of the variance of turnover is accounted for by the three explanatory variables of interest. (Plant availability, utilization and maintenance cost).

Table 3.7b: Coefficient estimate on the impact of Plant availability, capacity utilization and maintenance cost on production output

\begin{tabular}{|l|l|l|l|l|l|l|}
\hline Production output & Coef. & Std. Err. & $\mathbf{t}$ & $\mathbf{P > t}$ & [95\% Conf. & Interval] \\
\hline Plant Availability & 0.0029376 & .0012485 & 2.35 & 0.021 & .0004529 & .0054223 \\
\hline Capacity Utilization & 0.0191525 & .0013635 & 14.05 & 0.000 & .016439 & .021866 \\
\hline Maintenance Cost & 0.0361941 & .0179914 & 2.01 & 0.048 & .0003901 & .0719981 \\
\hline Constant & $\mathbf{5 . 8 7 0 2 1 6}$ & $\mathbf{. 2 6 9 5 9 9 8}$ & $\mathbf{2 1 . 7 7}$ & $\mathbf{0 . 0 0 0}$ & $\mathbf{5 . 3 3 3 6 9 5}$ & $\mathbf{6 . 4 0 6 7 3 7}$ \\
\hline
\end{tabular}

Plant availability has $0.2 \%$ impact on Production output, Capacity utilization has $1.9 \%$ impact on production output, and $3.6 \%$ impact on production output. To every percent increase in the three factors, result shows that the production output will increase with $5.87 \%$

\subsection{Overall Equipment Effectiveness}

From the collected secondary data relating to the six major losses, OEE computation is shown below as per TPM concept.

Table 3.8: Planned Production Time and Equipment Downtime

\begin{tabular}{|l|l|l|l|l|}
\hline \multicolumn{2}{|l|}{ Cereal Mill Annual Production } & \multicolumn{2}{l|}{ Plant Availability (\%) } & $\begin{array}{l}\text { Capacity } \\
\text { Utilization (\%) }\end{array}$ \\
\hline S/N & Year & Production \\
$\mathbf{1}$ & 2010 & $31,631.52$ & 83.82 & 65.90 \\
\hline $\mathbf{2}$ & 2011 & $29,676.75$ & 84.24 & 61.83 \\
\hline $\mathbf{3}$ & 2012 & $29,425.55$ & 86.76 & 61.30 \\
\hline $\mathbf{4}$ & 2013 & $31,942.64$ & 78.97 & 66.55 \\
\hline $\mathbf{5}$ & 2014 & $25,925.54$ & 67.41 & 54.01 \\
\hline $\mathbf{6}$ & 2015 & $19,495.77$ & 57.12 & 40.62 \\
\hline $\mathbf{7}$ & 2016 & $26,887.03$ & 69.24 & 56.02 \\
\hline
\end{tabular}




\begin{tabular}{|l|l|l|l|l|}
\hline $\mathbf{8}$ & Total & $194,984.80$ & 527.56 & 406.23 \\
\hline $\mathbf{9}$ & Average & $27,854.97$ & 75.37 & 58.03 \\
\hline
\end{tabular}

\section{Source: Grand Cereals Ltd.}

Average plant availability ratio for the study period was calculated at $\mathbf{7 5 . 3 7 \%}$ and average

capacity utilization ratio was also calculated at $\mathbf{5 8 \%}$

\section{Table 3.8.1: GCL off Specification data}

\begin{tabular}{|l|l|l|l|}
\hline Year & Production output & $\begin{array}{l}\text { Defect \& reworked } \\
\text { product(Tons) }\end{array}$ & $\begin{array}{l}\text { Off } \\
\text { Percentage (\%) }\end{array}$ \\
\hline $\mathbf{2 0 1 0}$ & $31,631.52$ & $3,321.31$ & 10.5 \\
\hline $\mathbf{2 0 1 1}$ & $29,676.75$ & $3,768.95$ & 12.7 \\
\hline $\mathbf{2 0 1 2}$ & $29,425.55$ & $4,266.71$ & 14.5 \\
\hline $\mathbf{2 0 1 3}$ & $31,942.64$ & $6,644.07$ & 20.8 \\
\hline $\mathbf{2 0 1 4}$ & $25,925.54$ & $3,344.40$ & 12.9 \\
\hline $\mathbf{2 0 1 5}$ & $19,495.77$ & $2,612.43$ & 13.4 \\
\hline $\mathbf{2 0 1 6}$ & $26,887.03$ & $3,118.90$ & 11.6 \\
\hline Total & $194,984.80$ & $27,076.77$ & 96.4 \\
\hline Average & $27,854.97$ & $3,868.11$ & 13.77 \\
\hline
\end{tabular}

\section{Source: Grand Cereals Ltd.}

From the data above, quality rate was calculated at $\mathbf{8 6 . 2 3 \%}$

Table 3.8.2: GCL Cereal Mill Actual production volume achieved compared with Set production targets and plant capacity

\begin{tabular}{|l|l|l|l|}
\hline Year & Total Production(Tons) & Plant Capacity(Tons) & Target Production (Tons) \\
\hline $\mathbf{2 0 1 0}$ & 31,600 & 48,000 & 42,200 \\
\hline $\mathbf{2 0 1 1}$ & 29,700 & 48,000 & 42,200 \\
\hline $\mathbf{2 0 1 2}$ & 29,400 & 48,000 & 42,100 \\
\hline $\mathbf{2 0 1 3}$ & 31,900 & 48,000 & 40,500 \\
\hline $\mathbf{2 0 1 4}$ & 26,000 & 48,000 & 40,100 \\
\hline $\mathbf{2 0 1 5}$ & 19,500 & 48,000 & 40,800 \\
\hline $\mathbf{2 0 1 6}$ & 27,000 & 48,000 & 42,200 \\
\hline
\end{tabular}




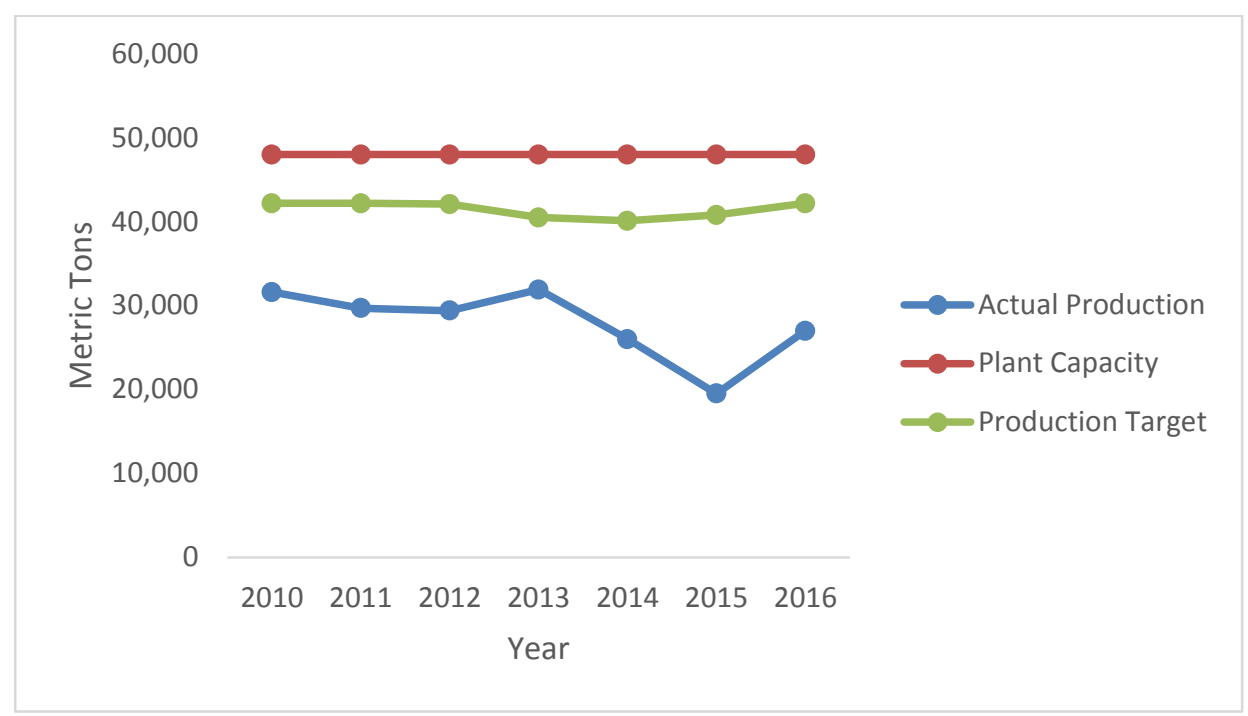

Figure 3.1 Cereal Mill Yearly Production levels

Table 3.8.2 and figure 3.1 show that from 2010 to 2012, Cereal Mill actual production output achieved dropped and then rose up in 2013.The volume output dropped again at a steady rate to 2015 and finally rose in 2016.Over the 7 year period the company Cereal Mill had failed to achieve its yearly target production levels and both the target production/actual production were far below the plant capacity. The low production output was caused by different factors such as unplanned stoppages of the machines caused by the shortage of critical spare parts, frequent breakdowns of machines and others. Using the data in fig.4, the Performance Efficiency was calculated at $\mathbf{5 8 . 0 3 \%}$

Overall Plant Effectiveness $=$ Availability ratio $\times$ Performance ratio $\times$ Quality ratio

Actual Plant $\mathrm{OPE}=0.7537 \times 0.5803 \times 0.8623=$ $0.3772=\mathbf{3 7 . 7 2 \%}$

OEE Comparison:

World Class OPE $=85 \%$

Actual Cereal Plant OPE $=38 \%$

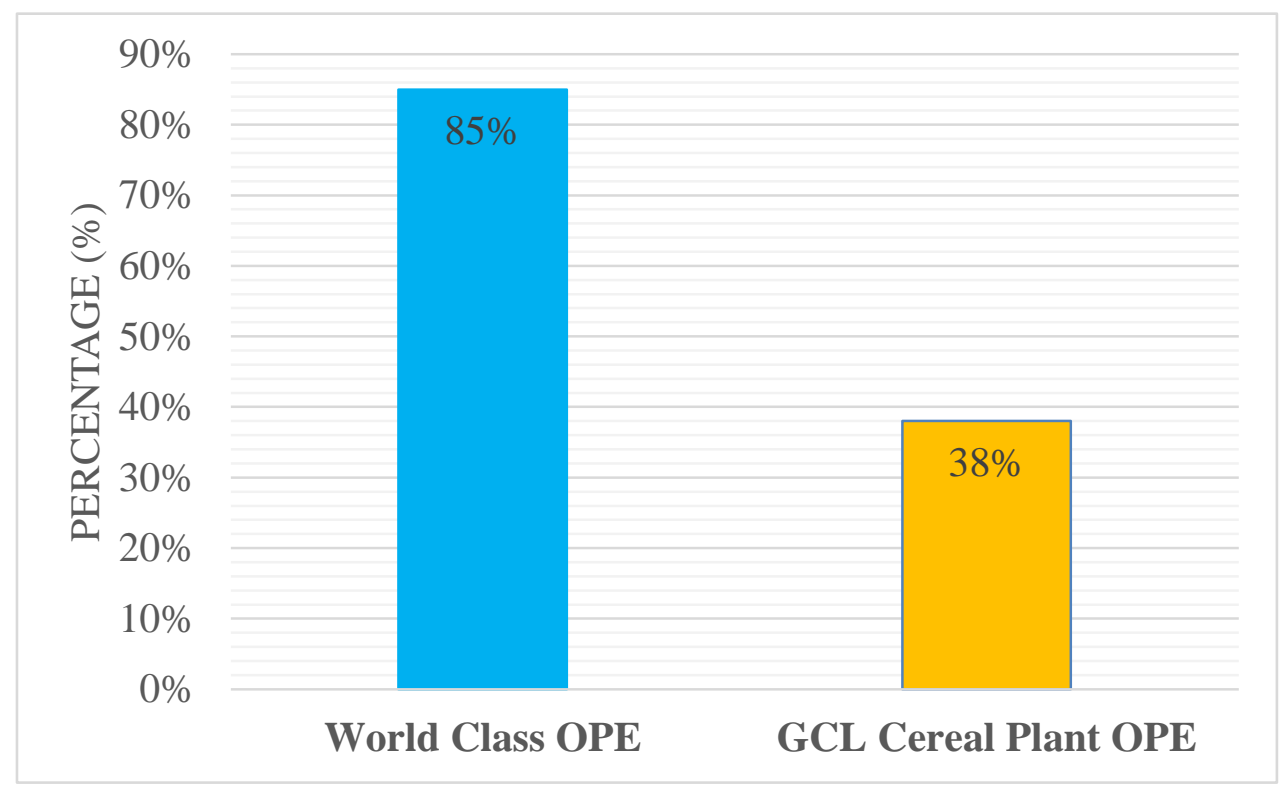

Fig 3.2 Comparison of GCL Cereal Mill plant OPE to the World Class OPE

Above shows the comparison of the world class OPE to the actual OPE of the plant under study. The actual Cereal plant OPE is much lower than the world class OPE by $47 \%$ (almost $50 \%$ ). Thus TPM implementation will help improve the OPE factors and Loss category.

\section{Conclusion and Recommendations}

\subsection{Conclusion}

The survey showed that the company does not implement TPM and Manufacturing output was found to have been directly affected by Plant 
availability, Capacity utilization and maintenance cost. It also revealed that there were bottle-necks at most stages of maintenance activities such as lack of funds, lack of tools and spare parts availability in the company, lack of manpower and trained employees to effectively carry out maintenance work on the machines and equipment. The research showed that the traditional maintenance strategy used by the company has a lot of gaps that can only be bridged by adopting Total Productive Maintenance methodology. This will go a long way in achieving reduction in production cost, increased manufacturing profitability, improved product quality, higher employee motivation and increased customer satisfaction.

\subsection{Recommendations}

This study hereby recommend the following:

i. Adoption and implementation of Total Productive Maintenance can minimise losses to the barest minimum thereby bringing about increase in the industry's profitability and image, both of which will ensure its competitiveness in the current economic turmoil.

ii. Maintenance activity should be considered as the potential profit area to use as a competitive advantage. Otherwise, higher operational costs will be incurred after the equipment deteriorates which directly affects the competitiveness of the company.

iii. Empowering the equipment operators and maintenance personnel through education and training will help bridge the identified competency gaps.

iv. Proper documentation of operational activities will help the industry implement Overall Plant Effectiveness (OPE) and Overall Equipment Effectiveness (OEE) as performance indicators to track equipment efficiency and plant effectiveness in order to achieve higher targets.

v. Further research on application and role of Total Productive Maintenance (TPM) in other manufacturing industries in the country is hereby recommended. This will help to validate the claim or otherwise of nonapplication of TPM in the study industry.

\section{References}

- Chan, F.T.S., Lau, H.W., Ip, R.W.L., Chan, H.K. and Kong, S. (2005). Implementation of Total Productive Maintenance: A case study. International Journal of Production Economics, 95(2005)71-94. Retrieved from http://www.elsevier.com/locate/dsw.

- Mwanza B.G \& Mbohwa C. (2015). Design of a Total Productive Maintenance Model for Effective Implementation: Case study of a chemical manufacturing company. International Journal of Industrial Engineering and Service Science, 2015, IESS 2015.Retrieved from http://www.sciencedirect.com

- Madanhire, I. \& Mbohwa, C. (2015). Implementing successful total productive maintenance in a manufacturing plant. Proceedings of the world Congress on Engineering, 2015 Vol. II WCE 2015 July 1-3, 2015, London U.K.

- Renganathan, K. (2014).The Impact of Total Productive Maintenance Practices on Manufacturing Performance through SECS/GEM standard for Electronic contact Manufacturing Companies (Unpublished doctorate thesis). Centre for graduate studies Open University, Malaysia.

- Seng, O. Y., Jantan, M., \& Ramayah, T. (2017). Implementing Total Productive Maintenance (TPM) in Malaysian Manufacturing Organisation: An Operational Strategy Study. KINERJA, 9(1): 1-8.

- Struwig, F. \& Stead, G. (2010). Planning and designing and reporting. Cape Town: Pearson Education South Africa. 